\section{Definitive Presurgical CAD/ CAM-Guided Implant-Supported Crown in an Esthetic Area}

Vinicius de Magalhães Barros¹, Natália Rafaela de Assis Costa², Paulo Henrique Fonseca Martins², Walison Arthuso Vasconcellos ${ }^{1}$, José Augusto César Discacciati ${ }^{1}$, Allyson Nogueira Moreira ${ }^{1}$

\author{
'Department of Restorative \\ Dentistry, Dental School, UFMG \\ - Universidade Federal de Minas \\ Gerais, Belo Horizonte, MG, Brazil \\ ${ }^{2}$ Dental School, UFMG - Universidade \\ Federal de Minas Gerais, Belo \\ Horizonte, MG, Brazil
}

Correspondence: Vinicius de Magalhães Barros, Avenida Francisco Sales, 1614, sala 1101. Santa Efigênia, 30150-221 Belo Horizonte, MG, Brasil. Tel: +55-31-4102-0700. e-mail: viniciusmbarros@hotmail.com

\begin{abstract}
This paper describes the digital workflow from cone beam computer tomography (CBCT) to the installation of a definitive presurgical zirconium individual crown in a 19-year-old woman requiring implant replacement of a maxillary right lateral incisor. The patient had agenesis of this tooth and had completed the orthodontic treatment. CBCT was conducted and diagnostic casts were digitized. Virtual planning was completed by defining a prosthetically driven implant and a stereolithographic surgical template was produced. Good adaptation of a stereolithographic surgical template was verified in the working cast. Implant and abutment were installed in this cast using a stereolithographic surgical template, and a CAD/CAM definitive zirconium crown was produced. Flapless computer-guided implant surgery was performed. The abutment was connected, and a definitive zirconium crown was cemented using resin cement. The digital workflow presented herein shows high accuracy for a virtually planned implant with flapless guided placement, allowing the successful delivery of a definitive presurgical zirconium single crown in an esthetic area in a single visit. The patient was revaluated after 1 year of function with an excellent outcome of the treatment.
\end{abstract}

Key Words: computer-guided implant dentistry, dental implants, image-guided surgery.

\section{Introduction}

Since the mid-1960s, when Branemark and colleagues described osseointegration (1), extensive research has been conducted to evaluate the long-term outcomes of dental implants (2). In modern dentistry, dental implants have considerably improved the rehabilitation of edentulous patients.

The osseointegration phenomenon is fully established, and dental implant treatment is a very reliable procedure. More recently, dental implantology has emphasized nature-like tooth replacement, minimally invasive surgical and restorative techniques, as well as time and cost efficiency (3). In this way, computer technology is an amazing tool to achieve these new goals and is becoming more and more popular in dentistry (4).

Cone beam computer tomography (CBCT), as a threedimensional (3D) imaging tool in combination with implant planning software, facilitated the virtual implant planning defined by prosthetic and anatomical structural parameters (4-6). From this virtual implant planning, a custom static fit-template with drill guides is produced, resulting in precision transferring of virtual planned implant positioning to the patient, which facilitates the placement of the prosthesis at the end of surgery. This new approach, called LITORIM (Leuven information technology-based oral rehabilitation by means of implants), has demonstrated encouraging clinical results (6-9) and makes the implant placement with a computeraided design/computer-aided manufactured (CAD/ CAM) surgical template more predictable than freehand placement (6).

Although concerns about the accuracy of computerguided implant placement still remain (10), this protocol allows clinicians to perform successful flapless implant surgery, causing less discomfort to the patient and decreased operating time. A recent systematic review and meta-analysis of computer technology applications in surgical implant dentistry revealed a high implant survival rate (97.3\%) and total mean error of $1.12 \mathrm{~mm}$ at the entry and $1.39 \mathrm{~mm}$ at the apex compared to virtually planned implant positioning (6).

From this perspective, transferring 3D virtual planning in order to achieve accurate precision of flapless implant placement and a presurgical prosthetic reconstruction with an immediate implant loading are still challenging procedures.

This clinical report demonstrates a digital workflow from a CBCT until the installation of a definitive presurgical zirconium individual crown.

\section{Case Report}

A 19-year-old woman presented at the Post-graduate 
Implantology Clinic of the Department of Restorative Dentistry at UFMG Dental School with a chief complaint of requesting implant replacement of a maxillary right lateral incisor. The patient had agenesis of this tooth and previously had completed orthodontic treatment. At the time of the first appointment, she was still using

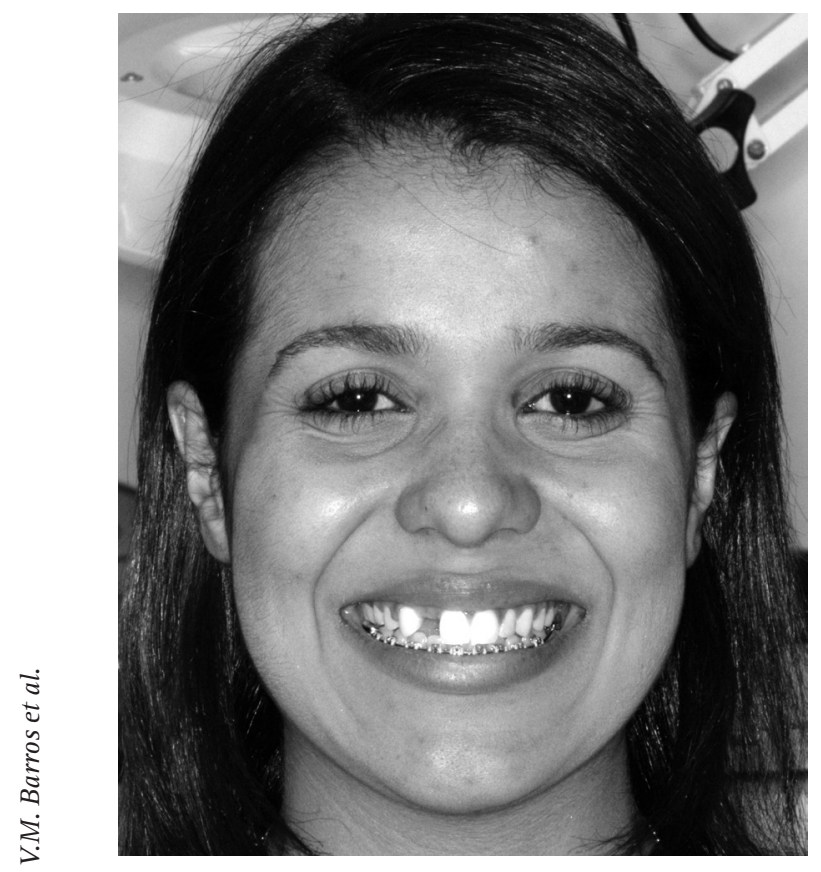

Figure 1. Pretreatment condition, showing the frontal view during smile. an orthodontic appliance to retain a provisional crown. Clinical intraoral and radiographic examinations showed no contraindications for dental treatment. The patient presented an average smile, revealing all teeth length and gingival papillae (Fig. 1). The residual alveolar ridge presented minimal width atrophy and no high atrophy. Tooth color selection and chromatic mapping were performed.

Cone beam computer tomography (CBTC) was used as part of the initial workup. Diagnostic impressions of the maxilla and mandible were obtained using irreversible hydrocolloid material (Hydrogum 5; Zhermack; Badia Polesine RO, Italy) and were poured in type IV stone (Elite Rock; Zhermack). These resulting casts were sent to a dental laboratory, and a lab scanner (D700 3D Scanner; 3 Shape, Copenhagen, Denmark) was used to obtain virtual casts.

The virtual diagnostic waxing was produced with the use of a virtual implant planning software (SimPlant; Materialise Dental, Plymouth, MI, USA). The digital stereolithographic files (STL) were merged with the Digital Imaging and Communications in Medicine data (DICOM) from CBTC into the same virtual implant planning software (SimPlant; Materialise Dental). Virtual planning was completed by defining a prosthetically driven implant (CM Titamax EX $3.5 \times 13$ mm; Neodent, Curitiba, PR, Brazil) and abutment (CM exact anatomic abutment; Neodent) (Fig. 2). The approved virtual plan was then transmitted to a 3D printer (ObjetEden

Q
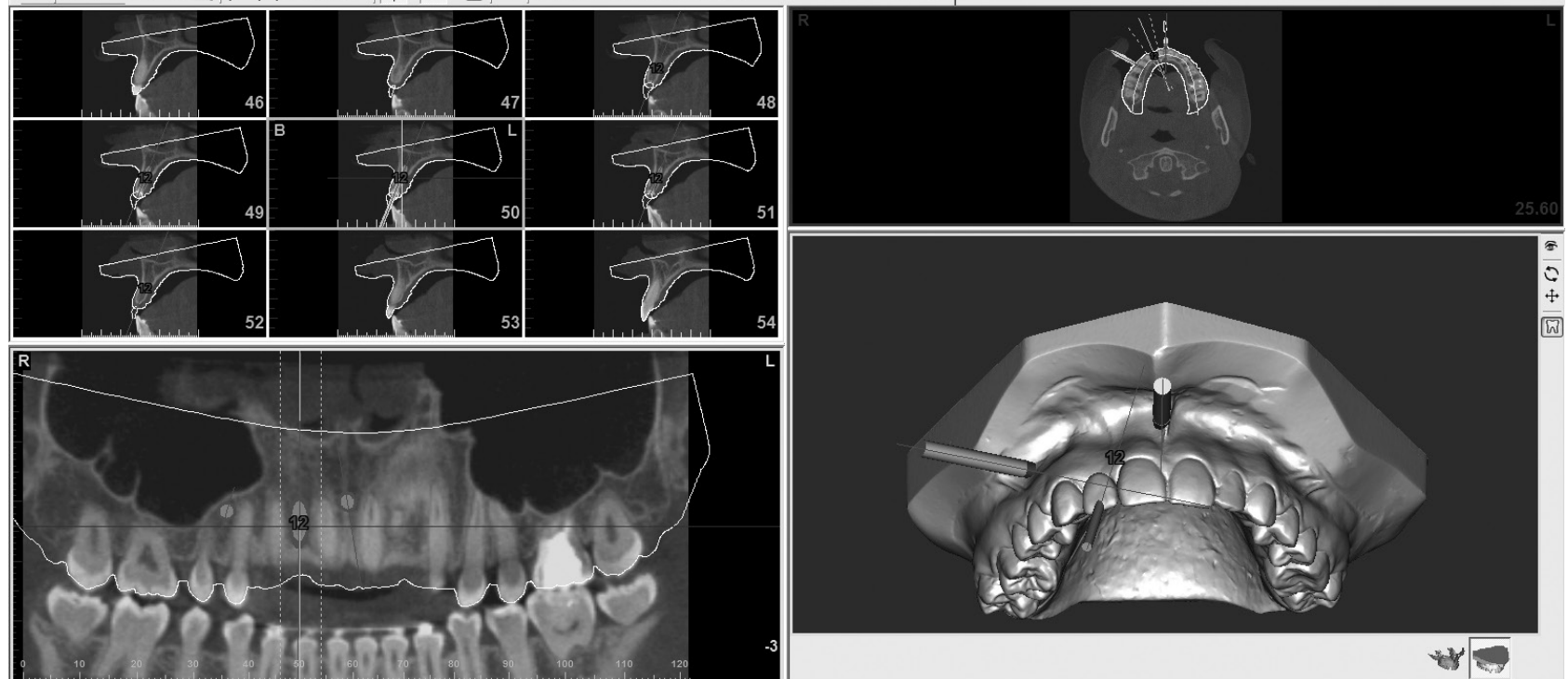

Visit www.simplant.com

Gray Scale: Original scale (level 664, width 5911)

Figure 2. Virtual implant planning software view. 
250; Stratasys, Rehovot, Israel) for the production of a stereolithographic surgical template.

Then, new impressions were made of the maxilla and mandible using irreversible hydrocolloid (Hydrogum 5; Zhermack) and were poured in type IV stone (Elite Rock; Zhermack). A definitive CAD/CAM presurgical prosthesis was produced using these maxillary and mandibular casts. Good adaptation of the stereolithographic surgical template was verified in this new cast. The maxillary cast was adapted and fixed in the die cast apparatus (Bafix, Desarollo e Tecnologia de Sistemas Dentales; Madrid; Spain) using epoxy resin (Loctite Durepox; Henkel, Düsseldorf, Germany). The cast was sectioned and the edentulous area removed.

With the stereolithographic surgical template adapted over this sectioned cast, an implant was fixed with type IV stone (Elite Rock; Zhermack) using an implant mount for guided surgery (Figs. 3A-D). These master casts were mounted in a semi-adjustable articulator and the preplanned abutment was attached into the implant. This abutment had no indexing device. A CAD/CAM definitive zirconium coping was produced (Lava; 3M, Saint Paul,
MN, USA), and the veneering porcelain was applied (VM9; Vita Zahnfabrik, Bad Säckingen, Waldshut; Germany) (Fig. 4). At this moment, an indexing device was produced to guide the abutment installation.

Flapless computer-guided implant surgery was performed (Neoguide; Neodent) under local anesthesia. The stereolithographic surgical template was supported by teeth and fixed by two stabilization pins. Using appropriate drilling guides and twist drills, a pre-planned implant (Titamax CM EX, 3.5 X 13 mm, Neodent) was placed guided by the stereolithographic surgical template. In the final moment of implant placement, a morse tapper connector was used to certify the precise vertical implant positioning (Fig. 5). The insertion torque was set at $32 \mathrm{~N} /$ $\mathrm{cm}^{2}$. The previously produced indexing device was used to connect the abutment (15 N/cm²) (Fig. 6). The definitive zirconium crown was cemented using a resin cement (Rely X U200; 3M) (Fig. 7).

The patient was revaluated clinically and radiographically 1 year after completion of the treatment, showing an excellent outcome regarding esthetics and function (Figs. 8A-C).
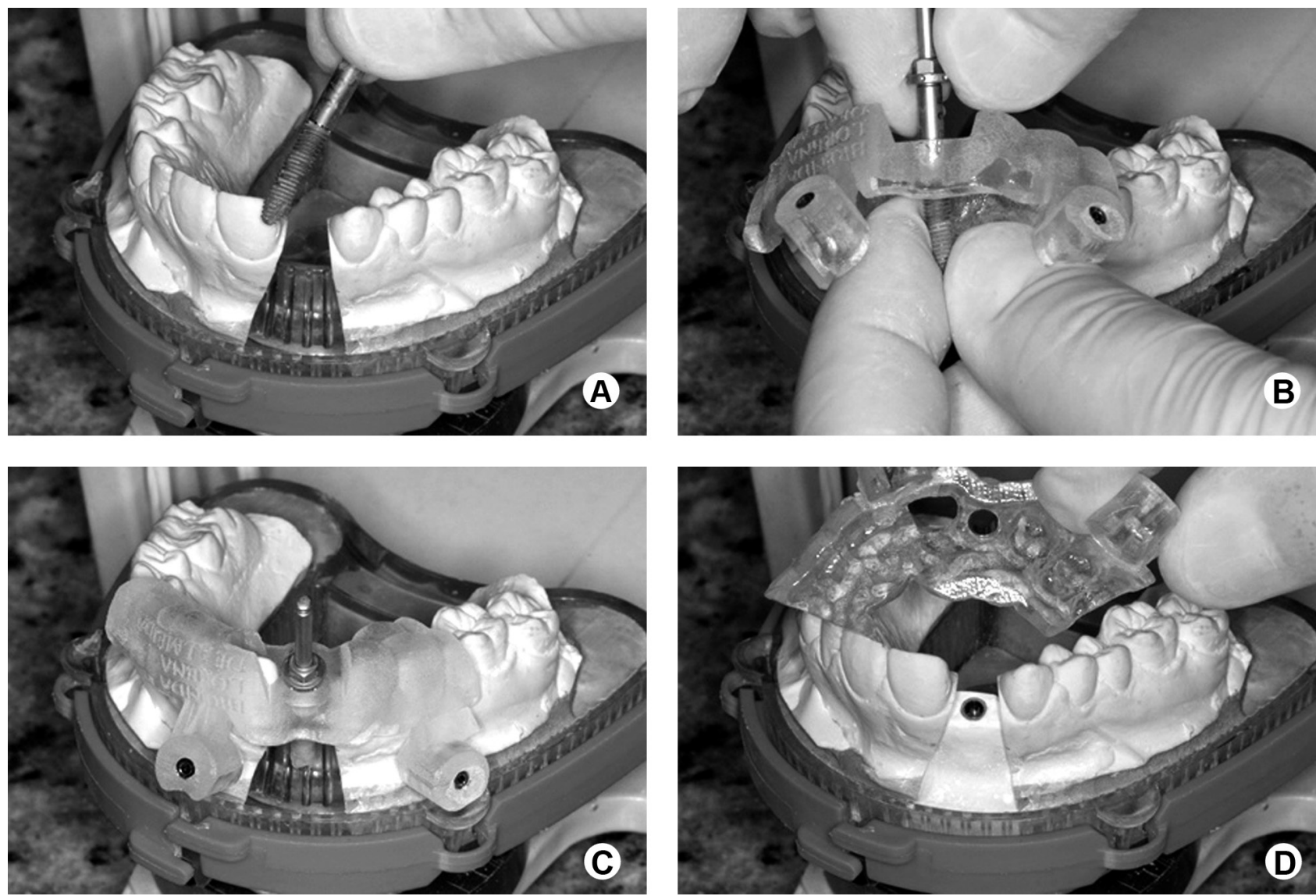

Figure 3. Fixation of an implant in the master cast using a stereolithographic surgical template. A: Sectioned cast, implant and implant mount for guided surgery. B: Implant and implant mount for guided surgery adapted over stereolithographic surgical template. C: Good adaptation of the implant, implant mount for guided surgery and stereolithographic surgical template over the sectioned cast. D: Implant fixed on the master cast. 


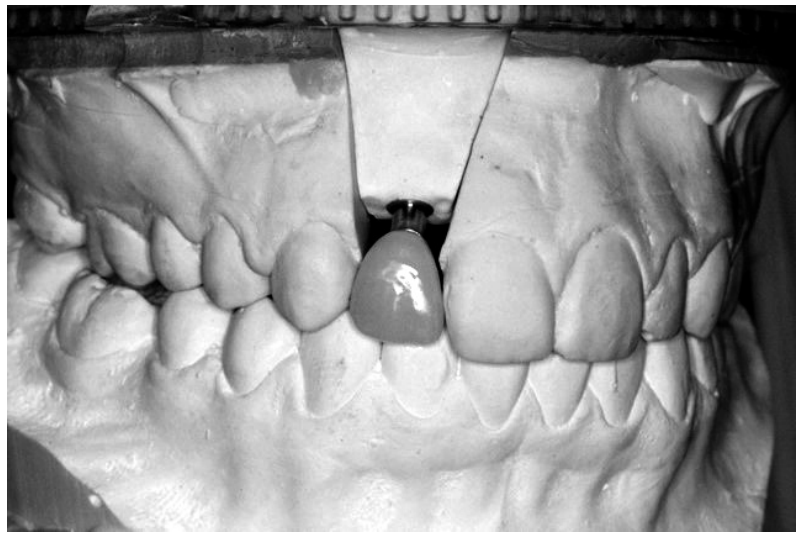

Figure 4. CAD/CAM definitive zirconium crown.

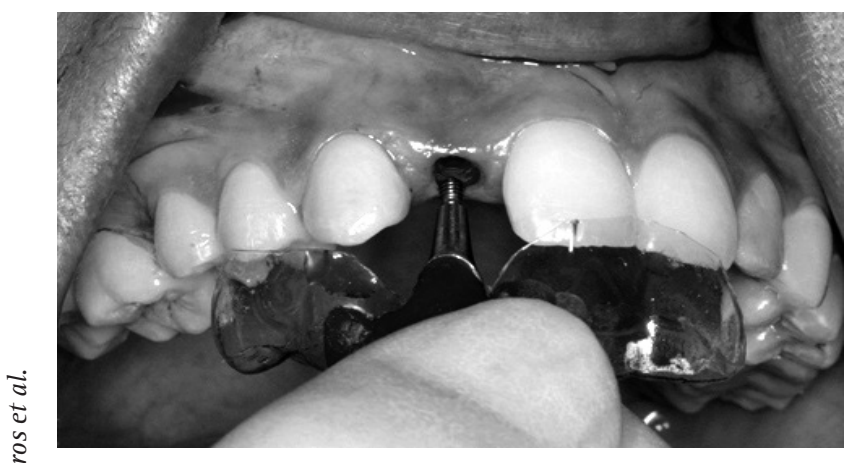

Figure 6. Abutment connection using the indexing device.

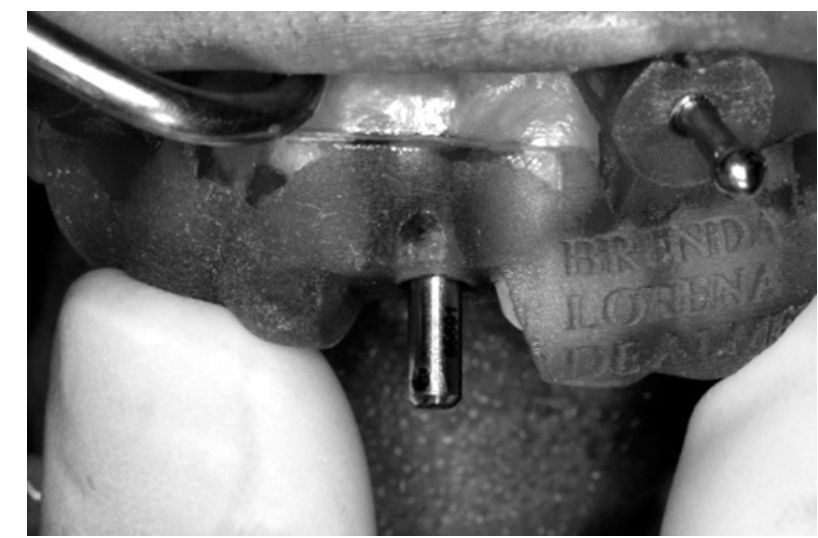

Figure 5. Morse tapper connector to confirm the precise vertical position of the implant.

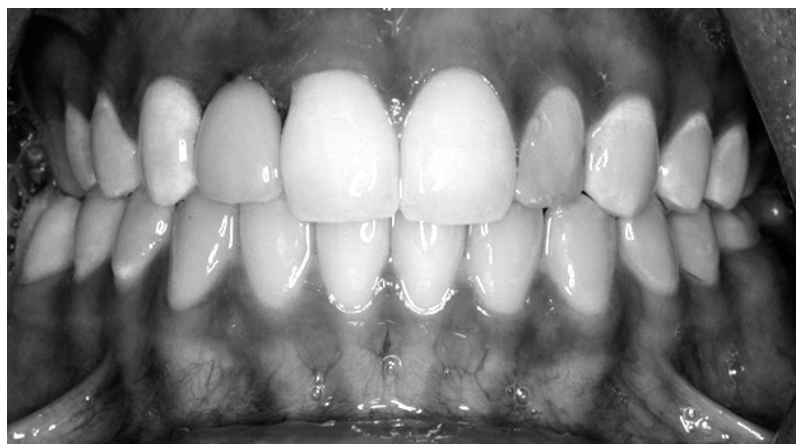

Figure 7. Definitive zirconium crown.
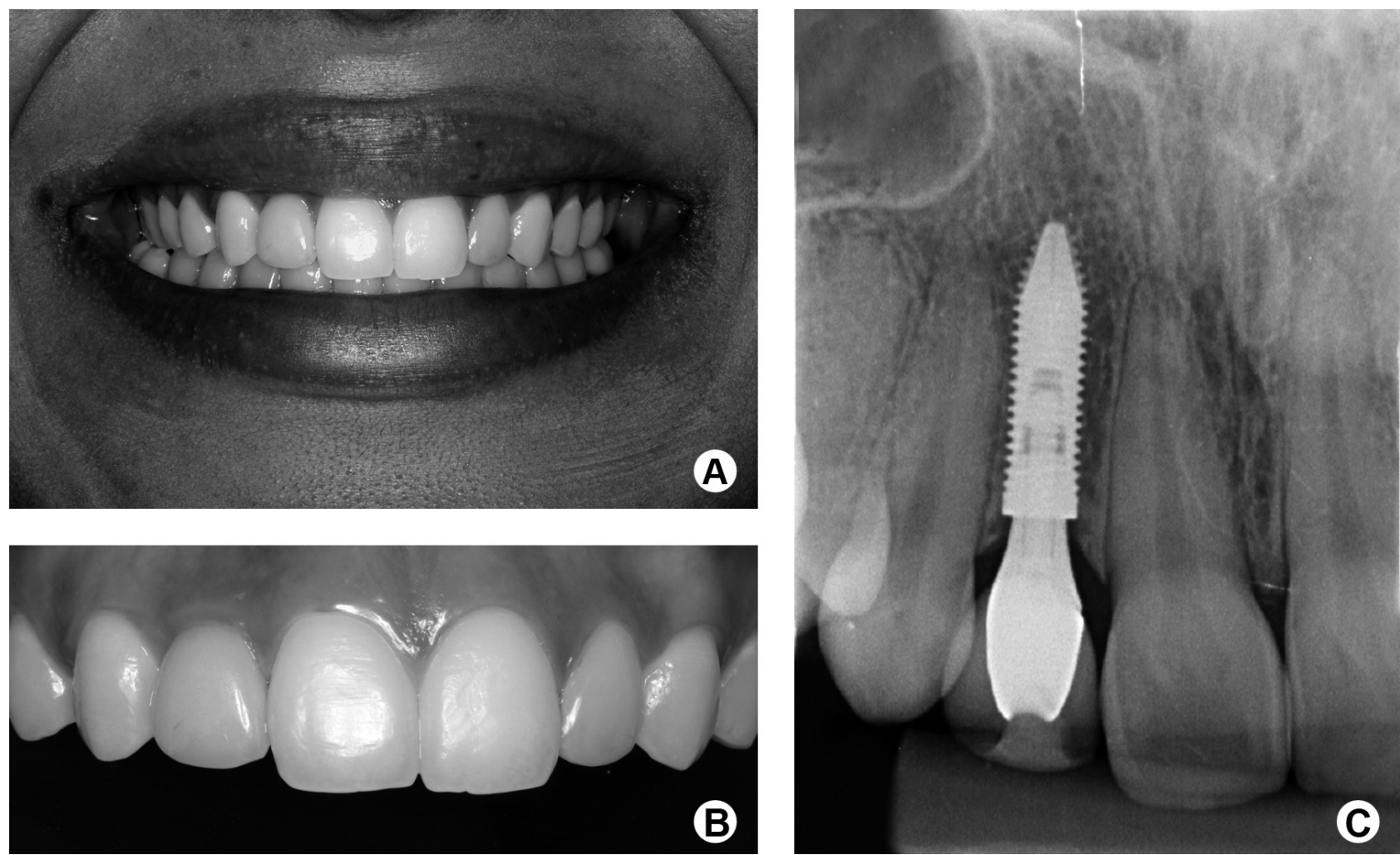

Figure 8. Post treatment one-year control. A: Smile view. B: Frontal view. C: Radiographic examination. 


\section{Discussion}

Increased patient comfort, rapid postsurgical healing, less traumatic surgery, fewer postoperative complications and decreased operative time are some advocated advantages of flapless implant surgery. On the other hand, this technique may increase the risk of unwanted bone perforations, secondary damage that increases the temperature during the bone preparation and higher marginal bone resorption (11-13). Despite the controversies of different implant failures in flapless or conventional flapped dental implant surgery $(6,11)$, the high survival rates (97.3\%) after 1 year (6) and 5 years (95\%) (14) encourage the use of this procedure. In the present case, the patient had sufficient keratinized gingival tissue and bone volume, so we adopted a flapless implant surgery. Likewise, flapless procedures seemed to show a significantly better accuracy than the flap approach (6).

The performance of static computer-guided implant systems and their accuracy depend on all the cumulative and interactive errors involved, from $\mathrm{CBCT}$ acquisition to the surgical procedure.

The surgical template used in this case was supported by teeth, which may contribute to great accuracy. The literature reports that bone-supported surgical guides are less accurate than those supported by teeth or mucosa (6). In the same manner, the use of guided implant placement probably has contributed to the clinical success observed in this case (6).

Other authors have used some adjustable abutments $(12,14,15)$ or cementation over metallic cylinder $(7)$ to guarantee correct fit of full arch definitive presurgical prosthesis. On the other hand, Tahmaseb et al. (16) using provisional mini-implants, inserted prior to the main surgery as a reference implant, achieved a level of accuracy that allowed a passive fit of full arch definitive presurgical superstructure connected to the implants without abutments. These authors revealed that in the first recall appointment, 1 week postsurgery, minor screw loosening had occurred in almost all patients. It may demonstrate the possibility of immediately loaded implant micromovement toward the framework due to tension induced by a small misfit in the implant-framework interface, similar to that verified in an animal study (17).

The concern about passivity was presented in a clinical report of a 3-element acrylic provisional implant supported by fixed dental prosthesis that was immediately loaded. This provisional presurgical prosthesis was separated with a diamond disk and reconnected intraorally with autopolymerizing acrylic resin to guarantee passive fit (18).

Mandelaris and VIk (19) presented a very similar case in the esthetic area where immediate guided implant placement in a fresh socket was performed simultaneously with placement of a CAD/CAM patient-specific abutment and non-occlusal provisional function. After 14 weeks, slight exposure of the abutment-provisional margin had occurred on the mesial aspect, and a new final abutment was designed and definitive crown was delivered.

Although computer-guided implant dentistry is an upcoming technology with the potential for more predictive and less invasive implant and presurgical prosthesis placement, achieving accurate precision with this procedure is still challenging, especially in partial edentulous or single esthetic cases. Two recent metaanalyses revealed a total mean error of 1.07 and $1.12 \mathrm{~mm}$ at the entry point and 1.63 and $1.39 \mathrm{~mm}$ at the apex $(4,6)$.

In the present case, we sought to achieve great accuracy for a virtually planned implant, and flapless guided placement allowed delivering a definitive presurgical zirconium single crown in the esthetic area in a single visit. The flapless surgery, surgical template supported by teeth, guided implant placement and the additional control of the vertical position of the implant probably contributed to the success. It must be noted that this implant was placed in a completely healed area with a thick peri-implant soft tissue biotype, so minor or no soft tissue changes were expected in a flapless implant placement, which was confirmed in a 1-year follow-up.

Considering the performance of the guided implant systems, in our view, the reduced treatment time and cost are the great advantages of this procedure. However, the presented case and workflow do not permit a trial insertion of the abutment and crown and in some cases may limit the esthetic outcome of definitive prosthesis. Other limitations are concerned about contact with adjacent and antagonist teeth. Both are related to a precise control of vertical implant positioning. In our view, this is the key to success of the present digital workflow. Another limitation is required additional training and experience for dentists and laboratory technicians.

\section{Resumo}

Este relato descreve o fluxo de trabalho digital desde tomografia de feixes cônicos até a instalação de uma coroa unitária pré cirúrgica definitiva em zircônia em uma mulher de 19 anos que necessitava de reabilitação com implante do incisivo lateral superior direito. A paciente apresentava agenesia deste dente e tinha finalizado o tratamento ortodôntico. Foi realizada a tomografia e os modelos diagnósticos foram digitalizados. 0 planejamento virtual do implante foi definido pelo planejamento protético virtual e em seguida um guia cirúrgico foi produzido pelo método da esteriolitografia. Foi verificada a boa adaptação deste guia cirúrgico sobre o modelo de trabalho. 0 implante e o pilar foram instalados neste modelo de trabalho usando o guia cirúrgico e confeccionada coroa pré cirúrgica definitiva em zircônia pela técnica de CAD / CAM. A cirurgia guiada de instalação do implante foi realizada sem deslocamento de retalho. 0 pilar selecionado foi instalado e coroa pré cirúrgica definitiva 
em zircônia foi cimentada com cimento resinoso. 0 fluxo de trabalho digital apresentado mostrou grande precisão para instalação guiada do implante em uma área estética, permitindo a instalação de uma coroa pré cirúrgica definitiva em zircônia em uma única sessão clínica. A paciente foi reavaliada e apresentou excelentes resultados do tratamento após um ano em função.

\section{References}

1. Branemark PI, Hansson BO, Adell R, Breine U, Lindstrom J, Hallen O, et al.. Osseointegrated implants in the treatment of the edentulous jaw. Experience from a 10-year period. Scand J Plast Reconstr Surg Suppl 1977:16:1-132.

2. Adell $\mathrm{R}$, Eriksson $\mathrm{B}$, Lekholm $\mathrm{U}$, Brånemark $\mathrm{PI}$, Jemt $\mathrm{T}$. Long-term follow-up study of osseointegrated implants in the treatment of totally edentulous jaws. Int J Oral Maxillofac Implants 1990;5:347-359.

3. Norkin FJ, Ganeles J, Zfaz S, Modares A. Assessing image-guided implant surgery in today's clinical practice. Compend Contin Educ Dent 2013;34:747-750.

4. Schneider $D$, Marquardt $P, Z$ wahlen $M$, Jung RE. A systematic review on the accuracy and the clinical outcome of computer-guided templatebased implant dentistry. Clin Oral Implants Res 2009;20:73-86.

5. Komiyama A, Pettersson A, Hultin $M$, Näsström K, Klinge B. Virtually planned and template-guided implant surgery: an experimental model matching approach. Clin Oral Implants Res 2011;22:308-313.

6. Tahmaseb A, Wismeijer D, Coucke W, Derksen W. Computer technology applications in surgical implant dentistry: a systematic review. Int J Oral Maxillofac Implants 2014;29:25-42.

7. van Steenberghe $D$, Naert I, Andersson $M$, Brajnovic I, Van Cleynenbreugel J, Suetens P. A custom template and definitive prosthesis allowing immediate implant loading in the maxilla: a clinical report. Int J Oral Maxillofac Implants 2002;17:663-670.

8. Verstreken K, Van Cleynenbreugel J, Marchal G, Naert I, Suetens $P_{1}$ van Steenberghe D. Computer-assisted planning of oral implant surgery: a three-dimensional approach. Int J Oral Maxillofac Implants 1996;11:806-810.

9. Verstreken K, Van Cleynenbreugel J, Martens K, Marchal G, van Steenberghe D, Suetens P. An image-guided planning system for endosseous oral implants. IEEE Trans Med Imaging 1998;17:842-852.
10. Bornstein MM, Al Nawas B, Kuchler U, Tahmaseb A. Consensus statements and recommended clinical procedures regarding contemporary surgical and radiographic techniques in implant dentistry. Int J Oral Maxillofac Implants 2014;29;78-82.

11. Chrcanovic BR, Albrektsson $T$, Wennerberg A. Flapless versus conventional flapped dental implant surgery: a meta-analysis. PLoS One 2014;9:e100624.

12. Johansson B, Friberg B, Nilson H. Digitally planned, immediately loaded dental implants with prefabricated prostheses in the reconstruction of edentulous maxillae: a 1-year prospective, multicenter study. Clin Implant Dent Relat Res 2009;11:194-200.

13. Migliorati $M$, Amorfini $L$, Signori $A$, Barberis $F$, Silvestrini Biavati $A$, Benedicenti S. Internal bone temperature change during guided surgery preparations for dental implants: an in vitro study. Int J Oral Maxillofac Implants 2013;28:1464-1469.

14. Sanna AM, Molly L, van Steenberghe D. Immediately loaded CADCAM manufactured fixed complete dentures using flapless implant placement procedures: a cohort study of consecutive patients. J Prosthet Dent 2007;97:331-339.

15. Kupeyan HK, Shaffner M, Armstrong J. Definitive CAD/CAM-guided prosthesis for immediate loading of bone-grafted maxilla: a case report. Clin Implant Dent Relat Res 2006;8:161-167.

16. Tahmaseb A, De Clerck R, Aartman I, Wismeijer D. Digital protocol for reference-based guided surgery and immediate loading: a prospective clinical study. Int J Oral Maxillofac Implants 2012;27:1258-1270.

17. Duyck J, Vrielinck L, Lambrichts I, Abe Y, Schepers S, Politis C, et al.. Biologic response of immediately versus delayed loaded implants supporting ill-fitting prostheses: an animal study. Clin Implant Dent Relat Res 2005;7:150-158.

18. Stapleton BM, Lin WS, Ntounis A, Harris BT, Morton D. Application of digital diagnostic impression, virtual planning, and computer-guided implant surgery for a CAD/CAM-fabricated, implant-supported fixed dental prosthesis: a clinical report. J Prosthet Dent 2014;112:402-408.

19. Mandelaris GA, VIk SD. Guided implant surgery with placement of a presurgical CAD/CAM patient-specific abutment and provisional in the esthetic zone. Compend Contin Educ Dent 2014;35:494-504.

Received August 3, 2015 Accepted October 5, 2015 